\section{THE RELATIVE VALUE OF THE "NATURAL" AND THE SYN'THETIC SALICYLATES}

\section{A S'UUY OF THE LIJERA'TURE* \\ CARY EGGLISTON, M.D. NEW YOKK CITY}

There is at present a fairly wide-sprend belief that the salicylic acid which is derived from the natural oil of wintergreen or sweet birch, and the sodium salt of this acid are to be preferred to the corresponding synthetic preparations. This preference seems to be founded mainly on two claims. 'I'he first is that the "natural" or "true" salicylates are less toxic than the artificial; the second, that they are more active as antirhemmatic arents. The adlierents of these vicws are very firm in their convictions, and, what is more, certain manufacturers make very positive statements regarding the relative superiority of the former componnds. On the other side of the question there are many who are equally certain that no such difference cxists. $\Lambda$ third class of physicians, those who are either neutral or who do not take a positive stand with either side, is probably greater than the two partisan groups combined.

If there is no difference in the toxicity or in the activity of the two classes of salicylates it is of considerable importance to know it, for the "natural" variety is about sixteen times as costly as the artificial. On the other hand, if the artificial is really more toxic or less active, or both, as is strongly urged, we would be unjustified in depriving our patients of the artvantages of the superior drug or in subjecting them to unnecessary risk of unfavorable effects from the more toxic, merely on the ground of economie difiference. It therelore becomes an jumportant matter to determine the validity of the several conflicting claims, if auch be possible. The (ommittee on Therapentic Researel of the Council on Pharmacy and Chemistry of the Ameriean Medical Assoeiation has undertaken the solution of this question and will approach it from several points of view. The results of biologic investigation liave already been published. ${ }^{1}$ 'The results of chemical examinations and of therapentie tests are fortheoming, and in this paper I shall attempt to review all of the evidence bearing on the question which can be found in the literature.

In the presentation of the results of my searches I shall endeavor to follow, as nearly as possible, a chronologic ordes, and for the most part 1 shall make nse of lileral quotations from the several prpers, thus letting their anthol's speak for themselves and avoiding the danger of misconstruing their statements.

In 18\% 4 Kolbe first described a means of manufacturing salicylic acid artificially from phenol. In $1876 \mathrm{Mac}$. Jagan" suggested the use of solicin in the treatment of rheumatisn, based on the coneeption that rheumatism was, as malaria was then supposed to be, miasmatic in origin, and that salicin, like cinchona, was a natural romedy, found growing in the regions in which rheumatism was most prevalent. From about 1875 on, the litelature on the beneficial action of one or another of the salicyl preparations in rheumatism grew apace, and along with the favorable reports came the records of untoward symptoms resulting from the new therapy;

- rhls investigation was ungertuken $n t$ the suggestion of the Commiter on 'jhernpentle Resenteh of the Council on Pharmacy and Chemtstry of the Amelienn Mredieal Association.

* From the Department of l'humacology of Cornedl Universily Medient college.

1. Waddell : Compalitlye Investigntion of the Effects and 'Tox felty of Sodium Salleylutes of Nuturul and Synthetic Origin, Arch. Int, Med., December, 1911, 1). 784.

a. Miclagan: Brit. Med. Jour., 1876, 1, 627. lout it is not until 18 ry that one finds any definite comparison of the artificial acid with the acid derived from the oil of winterereen or from salicin.

In that year Willinmsi read a paper on the impurities of the artificial acid, which he ascribed to the presenee of impurities in the parent phenol. He deseribed a method by which he was able to purify the artificial acid so completely as to obtain an acid identical in every way with the natural product. He thought that the impurity was probably a derivative of cresol (cresylic acid) and of this he remarked:

Respecting the medicinal properties of this acid $r$ can say nothing as yet; it may be, like paroxybenzoie acje, inert, and wonld then be simply a diluent of the sulicylic acid, or it may be active as an antiseptic, or it may be mischievous; whatever it he there can, I think, be no donlot that the artific. ial salicylic acid at present used for medical purposes is not so pure or so uniform as is desirable, and that it should bo more lighty purified and freed from this second acid I have described lefore it or its salts are nsed in medicine.

In the discussion of Williams' paper Professor Redwood is cited as saying:

Mr. Williams has done a grent deal townd nffording the explanation of $a$ fact which many had been aware of, namely, that the artificial salicylic acid sometimes failed in producing the effects antieipated, such as would be produeed by the natural acid.

Mr. Plownan confirmed fully the statement that artificial salicylic acid frequently caused considerable derangement to the system. It had been given in St. 'Thomas' Hospital in doses of 20 grains every two hours and the results lad frequently been to enuse delirimm. He was uncertain, however, whether the acid used was antificial or not, but from the price paid for it ho thought that it was probably artificial.

In $18 \% 9,1880,1882$ and 1888 , the Lancet contained papers by Maclagan defending his stand with regard to the superior antirhematic action of the natural salicylates as exemplified by salicin. Hils contentions were strengthened by oceasional reports of the unfarolable clfects of the impure artificial acid and its salts and it would seem that his views which jeferred the action of salicin to its presumed "natural relation" to rheumatism gained wide support and are, perhaps, to-day at the bottom of a similar idea regarding the difference between the actions of the "natural" salicylates and those of the artificial.

Following Williams, the next paper to appear bearing on the question was one by Fowler. 1881 from which I will quote:

In thirty-nine cases treated with pure salicylie neid [natural] toxic symptoms were present in ten only. In five there was deafness, in two denfness and timnitus, in threo denfness, timnitus and voniting. . . . As reands the relief from pain, subsidence of fever, and liability to relapse, the pure acid does not appen to net with greater benefit than the ordimary [artifieial] acid. . . . The advantages clamed for the pure acid are that it rarely produces vomiting and never delirium.

He also remarks that investigations which are going on show an impurity in the artificial acid, not, as yet, identified.

Fowler's olservations are too few to permit of very definite deductions but it is to be noticed that his short series slowed vomiting in 7.5 per cent. of the cases.

3. Willams: Phon Intur. and 'I'r, 1877-78, Series 3, vill, 785.

4. Jharm. Jour, and $T 2.1877-78$, vili, 796

5. Howler: 'Lancet, London, 1881, 11, 1118 . 
'This does not agree altogether with his further statement that one of the urvantages claimed is that the "true" acid, "rarely produces vorniting." 'This percentage may bave been a "lare oceurrence" of the symptom as compared with what was seen after the use of the artificial acid which was then on the market. His evirence in favor of the "true" acid is, then, not very strong, for he finds no difference in the antirheumatic powers of the "true" and the artificial acids, and his incidence of vomiting from the "natural" is by no means low.

Broadbent" expresses the belief that when toxic symptoms arise they are due to an impurity in the artificial drug. He says:

A question which we have not been able to resolve-indeed, J do not know that the material exists for its determination --is the relative advantages of the different salicyl eompounds. It seems to me that the "natural" salicylie acid, as being less jiable to contamination than the sumples made from coal-tar compounds, is preferable to the latter; and it is a matter for inguiry which no doulst will be sulumited to the test of exporienee, and which certainly $I$, for one, shall endeavor to elucidate.

Broadbent was a man of very wide experience as an internist and therapeutist, and yet he was able to offer no evidenes regarding the relative merits of these two acids. But his suggestion that it would be better in all probability to employ the "natural" must have had some weight in influeneing many of those who looked up to lime for guiclance. So fal as T have been able to discover he did not pulslish anything further on the subject.

Tatham, who was probably looked on as the greatest English anthority on rleumatism in his day, laid down the following rules to ensure success in the treatment of that disease:

First, the true salieylic acid olutnined from the vegetable kingrdom must alone be employed. If you have to give large dokes avoid giving the sutificial product obtained from earbolic acid, however much it may have been dialyzed and purified. An impure acid will very quickly produce symptoms closely resembling delirium trement. . . . Secondly, give the acid withont any alkali or base. . . . Thirdly, place the patient fully under the influence of the drug--that is, let him have suflicient to produce cereloral disturbance-- that is, burzing in the ears or lesdache, or slight deafuess. . . .

These sitatements are dogmatic and made withont reservation, and are presumalyly baserel on the results of his clinical observations. Infortumately, however, he cites no single case in sulsstuntiation of his statements. 'The reference to dialyzation and purification of the acid relates to the attempts by Dr. E. R. Sipuibl and other's to remove the impurities form the arlificial acid by dialysis. 'They claimed thus to produce a perfectly pure prodnet, bit it was subseruently shown that the impurities were not colloidal and that they dialyzed readily, so that the resulting product still contained much of the original impurity. latham mentions no disadvantage of the artificial acid other than the production of delirium, and his subsecfuent semarks calling for the use of enough of the "true" acid to cause cerebral symptoms such as tinnitus, deaf'ness and headache strongly suggest that if the "true" acid were corried further in it use, it, too, might bave given rise to dilirium. He does not compare the efficacy of the two acids nor does he spenk of the effects of the two on man in similar doses. His views must bave been of great weight at the time, but his failure to

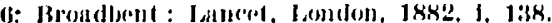

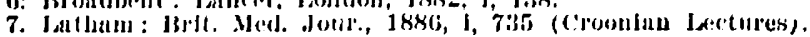

present the evidenee on which he based his remarks detracts materially from the seientifie value which can now be attuched to them. We do not know from him that the "true" acid did not also produce unfavorable: symptoms at times. We do not know that he ever used the artificial acid as a control. Sll that we do know from him is that he strongly alvocated the choien of the "natural" acial; why, he does not tell us, save for the mention of' the ilelirimm. 'J'he first experimental work done on the determination of the relative alvantages of the "natural" and artificial salicylates was that by Chasteris and Maclennan.

It is not within the scope of the present communic:tion to discuss the details of these experiments or to challenge their conduct; I shall deal only with the conclusions that have been drawn from the results they obtained and will refer the reader to an article by J. $\hat{\Lambda}$. Waddelp for detailed consideration of the individual experiments.

From their experiments they make the following detuctions:

These experimenty prove . . . that sulicylic acial olstained naturally by oxidution of walicin, or from the oil of wintergreen, in 10,grain doses, has . . . no deleterions effect; that sulicylate of soda obtuined from the naturnt salicylic acid, in 32 grains, is not letlaul, but that it enuses prostration and lowers the temperature.

On the other liund, it is conclusively demonstrated that salicylic neid, artificial, in a lo-grain dose, canses first, paralysis of flexors; secondly, denth by violent convulnions. Sodium salicylate, artificial, in 18 -grain doses, is lethal. . . .

'The deductions from these experiments indiente that artificial salicylie acid and its salt of sodium the dungerous and in large doses fatal to animale, while . . . mutural salicylic acid and its walts of soljum are not.

They believe that this difference depends doubtless on some impurity in the artilicial acid. 'l'his conchusion is strengthened by a letter which they received from G. G. Henderson of the chemical laboratory of the University of Glasgow, giving the results of his examination of saniples of the two acids used by the anthors. He foumd that the artificial was impure, containing "a small quantity of another acid which I have no doubt is the cause of the appearances observed alter the use of artificial salicylic acid." Further, he says, "I should add that no trace of this substance is to be foumd in natural salicylic acicl."

Subseduently Tenderson isolated this impurity and Clanteris and Mademan tested it, finding that "the action of this impurity seems to be of the nature of a slow bat certain poison, and the lethal dose is relatively much less than that of sallicylic acid."

\section{'They close their' palper with the following:}

'lhe obvious eonclusions from these experinents are that artificial salicylic acid combains nu inpority or impurition. und until this or these enn be extructed by the nid of ehem. istry the internal molministration of it or its salt of modium should be diseomitennneed. Jarge nud reponted dosem of the sodium salt are necensary in the treatiment of nente rhoumatism, and henee we may account for the restlessness, the confusion, and the delirium sometimes nttendant on its use, which lanve been terstified by alinical experience. It is more than probable, too, that the retarded convalencence oceuring in some cases of acute rheumntism after the sulicylate trentment is due to the great and protructed prostration which the impurity or impurities give rise to. It is to be remenbered in connection with these symptoms that preseriptions of the salicylate of sodium are invariably made up, muless 
otherwise indicated, from the artificial and not the nutural sult."

The first criticism of the work of Charteris and Muc. boman is that they have drawn far-renching conclusions from decidedly insufficient evidence. They mate only three experiments with sodium salicylate, one with the artificial and two with the "natural"; and only two tests of the salicylic acid, one with each variety. Further, as remarked by Wadilell, ${ }^{1}$ all of these tests seem to have been mance on but two animals, one for the "naturnl," the other for the artificial. In addition, it is olvions that they tested the action of only one specimen of areh of the preparations. They therefore made no controls of the renetions of the animals they used, and established a lethal dose as the result of a single test. The specimens of the preparations which they employed may or may not have been representative of what was to be found on the market at that time. And yet from these: experiments on but two animals they offer without hesitation the explamation of many of the untoward sympfoms seen at times during the therapeutic administration of the drug to man.

If their statement is colrect regarding the dispensing of the artificial preparations, then how muny of those who have reported favorably on the beneficial eftects of the salicylates, without any specification as to which class of preparation they were using, have been, in finct, reporting the salutary action of the condemned artificiul products? On the other hand, if Martindale and Squire are correct, how many of the unfavorable impressions relating to the action of the salicylates have been founded on the action of the "Matural" preparations? 'The numbers there logion of these two gromps of reports which appeared at about this time and in which there is no mention macle of the somere of the preparation.

'Thus far (Yharteris and Maclemnan's case in favor of the "true" salicylates is none too strong; we shall hear more of their work later.

'The discussion of the paper by Charteris and Maclennan contrins some points worthy of our attention. Dr. Shaw remarked that "all the evil effects generally uttributed to the action of salicylate of soda were not due to extraneous causes. It was not only on account of price that it was preferred to salicin, as it was a more eflicacious drug. He had seen delirinm and hemorrhages following the use of salicin as well as after salicylate of solium."

Haig said that he thought that the toxic effects of sodium salicylate had been exagrerated, but that there was a great difference in the different specimons. Taylor said that he gave 20 grains of sodium salicylate [artificial] every two hours and found delirium by no menns uncommon. Myers "could not agree with the great clanger of producing toxic effects with that drug" [i. e., artificial sodium salicylate]. Bruce said that he could not agree with 'Taylor', for' he had rarely seen delirium, though he gave 15 grains or more every three hours. Tc thought the drug then in use finer than formerly, for toxic effects were rarely seen.

Shaw's remarks indicate that he considered many of the unfavorable oflects of salicylate administration as due to the action of the salicylute itself and not to the presence of impurities derived from the phenol in the poess of synthesis. He certuinly implies this construc-

9. In the sinue volume (Brlt. Med. Tour., 1889, 11, 1315) Mr. Martindule writes in regatid to thes stutement regarding the illing of presertptions: "I'be leverse fo the rule with all good dispensiug

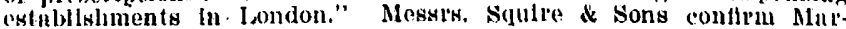
thidale's statement.

10. Brit, Med, Jour., 1800, 1, 350 tion when he further alds that he has "seen delirium and hemorthages following the use of sulicin as well as "a!ter salicylate of sodium."

Haig's statement to the effect that there was a great difference between different specimens of the artificin salicylate of soma serves to strengthen the similar sllogestion, which I male in discussing Charteris and Maclennan's results, that the specimens which they used may or may not have been representative of what was to be found on the market at that time.

'Tuylor's dose of the drug is rather high and it is not impossible that a similar amount of the "natural" salt would have produeed a like result, for in the paper by latham, he advises that sulfieient of the "true" acid be given, "to produce cerebral distmbunce," and subsequently says, "In the majority of cases 80 to 100 grains are cnough." It takes approximutely 115 grains of sodium salicylate to yicla 100 grains of salicylic acid so that. given in doses of 20 graims every two hours, only six doses would more than correspond to 100 grains of the acid. In addition Haig, Myers and Bruce could not agree with the experiences of 'Thylor.

The experiences, then, of those who discussed the paper of Charteris and Maclemm tend, il anything, to oppose the iden of greater toxicity of the artificial salicylate of sorium, and to refer such unfavorable effects as are seen to the action of an excessive amount of salicylute, regardless of its sourco.

We now return to Charteris ${ }^{11}$ and quote from a second paper of his in which he suys that "there has been a steadily growing conviction that artificial salicylate of socla . . . is dezressing, and further that in eer. tain cases there is cereloral excitement culminating in delirimn. . . " He cites the experinents which he had described in the preceding communications. He then relates having tested two samples of supposedly "pure" artificial ucid on rabbits, and 15 grains per $21 \%$ pounds were found to be tatal.

Next, he cites Willians, whom I have already quoted." Te followed Willians' directions for the purification of the artificial acid, preparing a pure salicylie acid which had the npenenence of the "natural" and a similar meltjng-point. He made three tests on rabbits with this purified and and found that "the result was most satisfactory"; "that there was no paralysis and no depression, but that, on the contrary, the animals were neither up nor down, but were able to rum about with ease after the last, injection."

As a result of these exporiments he remarks that "lhese facts show that the process of purification, even on a small scale, is not tedious or diflicult, and in all probability it conld be dome ensily and thoronghly on a large senle with less loss of time, and at only a slightly incrensed cost, as compared with the present method [1890]."

\section{Up to 1890 , he says:}

So fur we had found none [i.: e.: no specimens of urtiticial salicylic neidl nble to stand the physiologic test. . . . But on lan. 1, 1890), unsolicited, a Berlin tirm communicated with me through their agents in london. This firm sent speeimens supposed to be chemienlly pure, but when tested they were found to be not quite so, though relatively so. Since then speeinens of aeid have come from the same tirin which give the sume physiologic netion as that from the nutural salicylutes.

Te coneludes by saying, "For internal use in medi. cine they [phamrentical chemists] should demand the

11. Charteris : Med. Chir. 'lr., 18190, Ixxill, 141. 
large crystalline form of the artificial acid, and from this alone should the salicylate of. sola be prepared." Charteris had previously described the chemical and physical charneters of the "natural" acid and of the completely purified artificial product. 'Ihe two were the same.

'T'he results of this second set of observations by Charteris tend to show that the deleterious actions of the artificial acid were not inherent in the acid but were wholly dependent on the presence of an impurity, a view suggrested by most of the preceding authors, but, until now, not definitely established. They further show that it is quite possible so to purify this acid as to obtain a product laving the physical, chemical and pharmacologic characteristics of the "natural" product. 'That this process of purification is neither complicated nor unduly. costly seems to have been demonstrated by his work. Jastily the commercial purification of the artificial salicylate seems to have been accomplisher to the extent of yielding a product in no way different from the "true" acid. 'These results, coming from one who formerly was so powerful an advocate of the use of none but the pure "natural" product, are the more convincing, for there cam be no contention of blind adherence to a preconceived notion.

Charteris must certainly have convinced himself most firmly of the similarity between the completely purified artificial acid and the "natural"; of the equal efficacy of this purified product and the "natural"; and of the purity and efficacy of the sample of the commercially purified product, before expressing conclusions so diametrically opposed to those which he had previonsly expressed.

'The objection may be raised here that his methods were not checked up by control experiments in this latter work any mobe than they were in the former. This objection has lest much of its validity, for at the time of this report he had made tests similar to the earlier ones on a much larger number of animals and with a consid"rable number" of specimens of salicylic acid. Wach toit thus' made servod, in a measure, as a control for the susereeding. Nevertheless, it is regrettable that he still contented himelif with a few tests when he might have made his evidence vastly more valuable had he but doubIred or trebled their number.

In the same year that this last communication of Charteris' appeared, I)unstan and Bloch ${ }^{12}$ published a paper in which they enterel into a consideration of the chemical side of the relative purity of the two acids and discussed menns of purifieation. 'They say:

'llerapentic olsorvation las, however, disclosed the fret that both the commescial salicylic acid and that purified by dialysim produce eflects when achninistered to the human sulject which are not observed to result from the administration of the pure salicylic neid, prepared fiom the mothyl anlicylate contuined in the nutural oil of wintergreen.

They cite several observers who found from 6.5 per eent. to 30 or 40 per eent. of impurity in the commercial acid of that time.

'They further remark, "It will be seen . . . that the toxic action of the artificial salicylic acid of commeree has been definitely truced to an impurity.

They found ortho-, meta- and paracreosotic acids in the specinens which they examined.

Jo the same volume ${ }^{13}$ there is a report from Charteris on the results of hiologic tests of these creosotic acids on rabbits. He found the ortho- and para-acids highly toxic to these animals [two animals, one for each of the

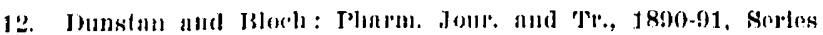
3. $\times \times 1,420$

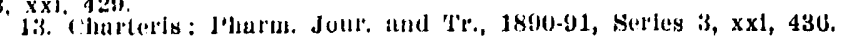

acids]. Metacreosotic ncid was non-ioxic. He further male two tests on rabbits of purified artificial sulicylic acid and found it to give satislactory results; i. e. that it was not toxic.

'l'o quote:

The ortho. and paracreosotic acids by their physiologic netion show that they are slow but certain poisons, eausing prostration and paralysis aflecting first the hind limbs and gradually extending over the boly.

The woll-defined erystalline form of the acid [artifiein salicylic] with a phelting-point of almost 157 C., mhonld be the oflicial form of the artificial salicylic acid, and from this alome should the salicylate of sodium be prepared.

I may mal that if salicylic acid be prepared from synthetic calbolie acid, baving a melting-point of $42 \mathrm{C}$., it then contains no impurity. Ity melting-point is $157 \mathrm{C}$., and, its pliysiolonic: action is in every way satisfactory.

'There is a fuller presentation of the same paper loy Charteris in the Brilish Medical Journal'14 from which I quote his closing remarks:

. . suflicient evidenese has been adduced to show that in cases where poisonous symptoms have been evoked by the administration of large and repeated doses of the artifieial salicylate of sola in-rhemmatism, they are dependent on its containing the infpurities mentioned [that is, o- and $p$ areosotic acids]. finther experiments may be necessary to determines whether the amount of paracreosotic acid contained in some samples of commercial salicylic acid is sulficient to produce poisonous eflects on a human sulject. My experiments show that when injected into small animals it is poisonous, though in a less degree than the ortho- neid, and that its poisonous eflects nre intensified when eombined with the ortho- nejo, and still mole so when incorpornted with this acinl and salicylic acid.

Regarding the sodium salt of paracreosotic acid he anys that ". . . judiciously given, [it] may be of benefit in certain diseases."

These three communications, the one by Dunstan and Bloch, and the two by (harteris, serve further to estal)lisw the fact that the unfavorable actions of salicylic acid and its sodium salt, derived synthetienlly, are not inherent in these preparations but are due solely to the presence of impurities which it is quite possible to remove completely. 'They further confirm the previous work which showed that the artifieinl salieylates when efficiently purified are plyssiologically identical with the colresponding "natura" salicylates.

In spite of the work done by Charteris it is diffieult to aceept his contention that paracreosotic acil is so much to blame for the production of the toxie effects as he says it is, for he himself admits that its sodium salt has been used in thempenties. In Germany at about this time sodium paracreosotate [paracreosotinate] was in nse in medicine and did not cause any severe toxic symptonts when given in closes of 5 granins ench. Further, in the light of the work of Waddell, ${ }^{3}$ we are almost forced to reject this idea. Waddell has also shown that "mixtures of paracreosotinate of solium with natural sodium salicylate do not exluibit greater toxicity than the components. . . "Jhis contradicts the previous stateinent made by Charteris regarding their combined action. Furtler, in a letter to the Brilish Medical Jonmal" Professor Stockman takes exception to the contention that the toxic impurity of artificial salicylic acid is creosotic [ereosotinici] acid. In this letter he says:

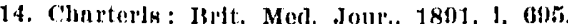
15. Stockman : Bsit. Med. Joll., 18:0, II, 1271. 
That this sulstance is not creosotic acid seems to me to be proved by the following considerations:

1. The results of rlinical experience with creosotate of solium; it was used by Buss (1876) in doses up to $4.0 \mathrm{gm}$., loy (intti (187!) in 5.0 to $8.0 \mathrm{gmm}$. doses, and by Demme (1889) in children up to 1.5 gm. None of these anthors observed that it had ally purticular poisonons eflects, and they angee in concheding that its action is practienlly identical with the retion of sulicylate of soda. It will be observed that Demme used puracresostic acid, which is stated by professor Chanteris to be so poisonous that 2 grains of it killed a rublit weighing $11 / 2$ pounds.

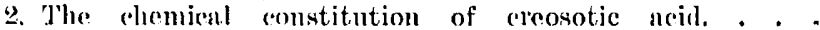
Chemienlly it is very asomy allied to salicylic acid, fund from what we nlready know of the relationship in physiologio action smong the members of this series, one could predicate with certainty that in action it would closely resemble sulicylic aceid.

Stockman is of the opinion that the specimens of creosotic acid which charteris tested also contained the same unknown impurity as did the salieylic acid he had previously tested.

May ${ }^{13}$ cites the smue observers as have just been montioned in the quotation from Stockman. He notes that Demme gave 90 to 120 grans of paracrensotinic acid to men without the production of toxic symptoms. May conducted some experiments on nan and animals with the severnl creosotinic aeids [creosotic] and conclurles by saying:

The creosotinie neids resemble salicylie acid in their ustion as antiformentatives, an lanctericides, as antipyreties, and as specifies in acute rhoumatism. Thoir toxio offect in animuis is "bout the same, but orthorreosotinic arid is more depressing to the circulation.

'These remarks ly May and Stockman merely throw doubt on the aceniney of the determination of the precise chemical nature of the body which was the eause of the deleterious action of the salicylic acid which $\mathrm{Cl}$ anteris used. and the trintl of the remurks of Stockmm wore, in tion, challenged by 1)unstan. It would cary us too far afield to consider this phase of the problem. All that concerns us at the prosent moment is the question of the purjefintion of salicylic acid and the action of the purified product.

Taling coenizance of these differences of opinion und the objections to Charteris' conclusions, we have not impared the validity of his work with regard to the lack of toxicity of the prirified artificial salicylates. And the nmmber of experiments which he had by this time done with the purified prolucts is sufficient to remove the objections on the ground of possible idiosynerasies on the part of his animats.

I might here make brief mention of ITenderson's' olservations on the question of the purfication of sulicylic: acid. He tried many methods and found that the very simple one devised by Willimms" was the most sntisfactory. He found as jimpurities areosotic acid. parahydroxybenzoic acid, and hydroxyisophthalie neid. To remurks, "It is therefore a comparatively simple matter" to manufacture a pure salicylic acid-indeed, I understume that this is now being done." (1890.)

Stoekvis ${ }^{18}$ seems to have been about the only man outside of Great Britain to make any studies on the relative advantages of the artificinl and the "natural" salicylates. He cites the paper of" "Chartens and Machyon," which is obviously intended as a reference to that of Charteris

16. Mny : Brit. Mod. Jour., 1909, II, T01

17. Henderson: Jour, Soc. (Jilen. Indust., 18!)6, $(x, 59) 1$

15. Stockvly: When. med. I'l'esse, 1894, xxxv, 1200. and Maclennan. Stockivis used the sodium salt of eneh of these acids.

His findings were, in brief: that the "natural" was much milder in its actions than the artificial; that the "natural" acid was exceted the more rapidly in the pab. hit and man; that with the more rapid excretion of the "natural" there was a marked diuresis in aldition (this was not true of the artificial), and that, in the smme doses, the actious of the "natural" were less marked on the rabbit than those of the artificial, but that the lethal doses were yaite the same. On frogs' hearts the salicylates caused depression, smaller doses of the artificial being required than of the "naturnl." He cites the experience of Moexel, who took the drug duily for fourteen lays in doses of 0.2 gnt. every four hours [about 3 grains form times a day]. On the first day he observed hendache, which soon passed off; there was no effect on sleep, appetite or otlser f'unction. 'The temperature was little altereit. These symptoms were less marked in the case of the "natural" product. The pulse-rate was somewhat incrensed by the artificial and less by the "natural." Respiration was raised in rate by the artificial, and prac. tically not at all by the "natiurnl."

'Paking all of the results torether, Stockvis remarks that there is hardly to be noted any qualitative difforence in action between the artiticial and natural. He says that one must ngree unconditionally with "Chartens and Machyon" that the dificrence is merely quantitative, and that the natural is the less toxic. That in the explanation of this difference the more rapid elimination of the natural plays a great part; this he attributes to "osmotic peculiarities" of this acid. He found that the electrical conductivities of the two ncids were not iden. tical, and that the "nutural" was impure ahemically, being mixed with an extremely small amount of oil of wintergreen. He suid that our next task would be to free the natural acid completely from the methyl-salicylester, and make comparisons of this with the pure artificinl acid.

He conchudes with the remark that "so much is cvident; that the chemically impure 'natural' acid is better therapentically than the chemieally pure artificial."

In view of all of the previous work, one cannot be but struck by Stockvis' conclusion that the milder actions of the "naturnl" salicylates are due to their impurity. while the artificial compounds are pure. Such a view must be taken with considerable reserve, for it is opposer to all of the chemical and pharmacologie studies which we have thus far reported. In lis work there is a further rather anomalous statement to the effect that. though the "natural" salieylates were found to bo "less: marked" in their netions than the artificial, the fatil Aose was the same for the two forms. When we reall that he also said that "there is hasdly to be noted ally qualitative difference" between the two, and that "the difference is merely quantitative" we are at a loss to know how to recomeile two contentions so completely antagonistic.

It may be true that the "natural" gives a greater diuresis than the artilicial, but just how this cxplams the "milder actions" of this product is by no mons colent. particularly in the exporiments in which the drugs were aplied to the frogs' hearts. Why his diuretic offect of the "true" reduces its nctions to a less marked grade, and does not similarly effect its lethal retion is also dif. ficult of comprehension.

The evidence brought forth by the self-made observitioms of Moerel is not convincing, for the differences lic cxperienced in the effects of the two salicylates are so 
slight as to be accounted for as being the results of the mychic influences of a preconecived idea. Finally Stockvis' failure to look further into the literature of the subject than the earliest work by Charteris aceords with the general superficial character of his observations.

lawin ${ }^{13}$ adds nothing to what has alseady been discussed, lout he repeats that the impurities of the artificial salicylic preparations are responsible for their side actions, such as delirium and cerebral excitement. While this is true regarding the difference between the actions of the two classes of salicylates, he remarks that it must be borne in mind that pure preparations are not devoid of side actions. 'These impurities are probably the ortho- or paracreosotic acids. His work is not original. It is merely his summary of the literature, with the stamp of his interpretation of the value of the several ideas suggested. I introduce this merely on aceount of the fact that what appeared in Iewin's book must have had some influence in molding medical opinion on aceount of the reputation of the anthor.

Along with the preceling it may be well to cite the monograpli by Pribjan," in which he reviews at length the greater part of the literature relating to the salieylate therapy of rheumatism. Tle details a very formidable array of unfavorable effects of the salicylates, without mentioning whether they resulted from the "natiral" or the artificial, and then remarks that it is obvious that many of these phenomena, including death, were probably in no way attributable to the action of the salicylate, on which the blame was thrown.

'The first of the American papers to deal with the question of the relative merits of the two forms of salicylate seems to be that by a phamacist, Cone. ${ }^{21}$ His evirence is eomposed of citations from some of the authors whose work I have already discussed, and from some whose paper's I lave been imaible to find, as (one gives no refereness. Among the latter jo one f'rom I)r. IH. M. Iyntan, who said, in an alderess, that he had had the following anly experiences with the use of salicylic acid and sodium salicylate: he "lound that the lesults were not so rood from preparations made in this country as from the orjginal (iemonn articke, due to imporities in the former." He reports a chse of delirimm tremens-like symptoms from its whe.

1)r. Simon Baluch is cited as saying that to get the effect from the salicylates without their inconvenionces, pure salicylic acid should be nsed; only that derived f'rom the oil of gaultheria should be employed.

Dr. Abraham Meyer is reported as saying that only the salieylie aeid from gemuine oil of wintergeen should loe need; that the others |i. e., the synthetie: and the sulieylic acid derived from the synthetic oill (anuse disturl)ance of the stomach, and delirium.

Alter citing the work of Charteris and Macelennan, of liunstan, and Charteris' second paper, Cone goes on to discuss the teste for purity and their ability to detect udulteration. He conceludes as follows:

At present a vary large pereentage of the oil of winter-

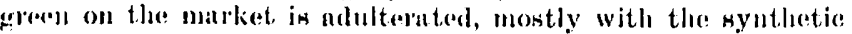
methyl salicylate, and this malteration has been the most diflicult to detect, ponmessisig, un it does, nbont the mame

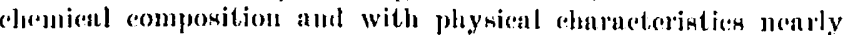
identikal.

l'ancoast and Pearson"2 also have entered into the sturly of the purity of the salicylio acid sold as "natural,"

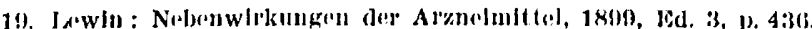

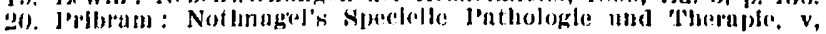
$1: 11: 12,44 ! 1$.

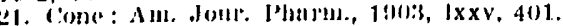

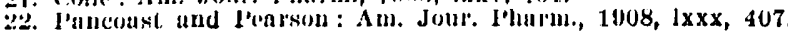

and, though it breaks the chronologie order, I shall bring in theip findings at this point and discuss the two juprers togrether.

\section{'They say:}

Nince the 'so-culled natural salicylates have met with such wida-spread fatvor as therapentic agents, there has been a tendency on the part of a few unserupulous distillers, dealers and drug morchunts, to substitute the low-priced synthetic probluets. 'I'his tendency hus more rmpidly grown as there lans been no acenrnte menns of detecting the sophistication.

For nome years chemists have endenvored to detect the presence of synthetic methyl salicylate when added to oil of lireh or gaultheria, but, owing to the great similarity of these products, the task has been very laborious. All three of thene products contuin at lenst 99 per cent. of absolnte methyl salicylinte.

While these two papers from pharmacists add very litthe of value from the elinical or experimental aspects of the question, they are of interest hecause they serve to show how slight the chemicnl differences between the "Inatural" and artificial salicylates are-not over 1 per cent. aceording to one-and how difficult it is to be eertain that one really has the "natural" product, and not, in fact, a combination of the two. 'This suggests a little cloubt as to whether all of those who have praised the "natural" salicylates so highly have in reality been using the drugs they lauded, or only mixtures of "natural" with the artificinl. 'This applies particularly to the elinial reports, for in most of these the question of purity of the product was not juvestignted. The vast difference in the price of the two classes ol salicylates makes arulteration finr more probable than not in many instunces. It is not improbable, then, fitat many have wnwibtingly sung the praises of the artifeial in the belied that it was the pure "natural" salicylate.

'The last three papers which T shall present are from American authors and are purely elinical in character; lonce they are subject to the eniticisms which I have just made regarding the possible impurity of the products used. It is eertain that the anthors were sincere in their beliefs that what they used was only the "natural" salieylate; but who is to rheek the purity of the salieylate that the local phamuacist uses in preparing the preseription? Ifven jt he be acting in good faith, it is not probable that he can be any more certain of the purity of the preparation that is sold to him than is the plysician of that he receives from the dloggist.

The first of these papers is liy I)r. Winters;23 in it he spealis of the salicylates only in the comrse of the discussion of the treatment of rhemmatism. He says that there is a positive chemical antidote to rhemmatism and that "this antidote is an oryanic chemical compound. Synthetice salicylic: acid has no efferet." The gives no data on which he buses these stutements. This is the strongest support of the "natuml" sulicylie neid and the most severe conclemuation of the syuthetic that I have found.

The secomf is based on the olselvations of Rosen\%weig and Romginsky. ${ }^{2+}$ As the result of some elinical observations on the artilicial mol "naturnl" sulicylic acils they reported, "l'he 'naturnl' product does not depress the heart as much as the artificial procluet; it does not upset the stomach so much; it nets more rapidly." Tilise the preceding anthor, they do not give the Gata on which they base their atutements; the statement quoted ubove was, in fact, reported as coming from them by a third person, D)'. Kalin, who had asked them to make the

23. Wintere, J. LS: Jillology of Rlommatism, ete., pamphlet publestied by nuthor.

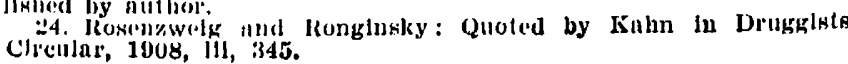


observations. This kind of evidence is certainly far from convincing and has no scientific value.

The third of these papers is by Dr. Lambert, ${ }^{25}$ in which he strongly advocates the use of the oil of sweet birch in preference to the synthetic salicylates, and in fact in preference to any other of the salicylates. $\mathrm{He}$ bases this on clinical experience and while he thus advocates the use of the "Inatural" salicylates, he does not by muy means exclude the uscfulness of the artificinl, for he speeifically says that if one of the common forms of salicylate does not agree with the patient we should try others nutil we find one that does: " . . . if the patient is resistant to that [true oil of birch], it slould be changed to . . . some other form of salicylate."

It does not seem necessary to enter into a separate discussion of the last three papers, for such of the previous criticismıs as apply wonld only have to be repented.

Before summarizing it may be of interest to cite from two personal communications from l'rofessor Stockman of the University of Glasgow to one of the members of the Committee on Therapeutic Research of the Council on Pharmacy and Chemistry. From the first, written in Oetober, 1911, I shall quote:

Some yeurs ago I exumined five samples of nrtificial sodium salicylate from different manufacturers. I found that four of them were practically chenioally purc, and differed in no say as regards clinical action, and chemical tests from the "malural" sodium sulicylate. ${ }^{-0}$ So far therefore as my own experieneo goes I regard the matter as settled.

ITe further" says that "gross differences certainly do not exist between the actions of pure artificial sodium salicylate and the so-called 'natural' product." In a second comminication he says that he has gone inte the question of the "natural" and synthetic salicylates and he has "found that the pure synthetic acid is not more poisonous than the other ('natural')." He also finds, as a result of therapeutic exuminntions, that creosotic (creosotinie) acids "can be given in doses similar to those of the salicylates."

Before drawing any conclusions from the material which I have been able to collect as bearing in any way on the question of the relative value of the artificial and "natura" salicylates, I. shall briefly summarize the evidence brought forth in the papers and discussions which are here presented.

There is first the clinieal evidence. I have been able to find only fourtece expressions of opinion from the clinieal point of view favoring the "natural" salicylates over the artificial. One of this group (Maclagan)" speaks only in favor of salicin, and his reasons for his views go far to invalidate his contentions. A second (Charteris) favored the "natural" in his first pitper only, and subsequently specifically advocated the use of the pure artificial salicylates. A third (Lambert) favors the "natural" but does not condemn the artificial, using it when the "natural" is ineffective. The rest of those who favor the "natural" salieylates in general give no evidence in support of their contentions, merely stating their views more or less firmly. 'Two do give elinical evidence for their contentions (Fowler and Stockvis), but in neither case is the evidence at all convincing. Only two (Maclagan, Winters) have challenged the therapentic value of the artificial salicylates.

Second, there is the chemical evidence. This is of a positive nature and the findings are, in all probability, quite correct. It is to be remarked, however, that such,

25. Lambert: Tho Use of Sulicylates in Rhemmatism, Tum JounNAL A. M. A. Sept. 0,1011, p. 808.

20. Itrilics mine. findings apply only to preparations on the market prior to 1900 , and there is no evidence to show that the synthetic preparations of the present day are not chemically pure. There is, in fact, evidence to support the view that they are pure (Waddell ${ }^{1}$ ). On this point we must remember that there is reason to believe that sodium paracreosotinate in small amounts is not toxie to man, ${ }^{1,15,13}$ and this is the ehief impurity blamed for the alleged inferior worth of the artificial salicylate.

There is experimental evidence from three sources only. First is that from Charteris, and Charteris and Maclennan. 'lihis ultinutely showed that it is commercially possible to purify the artificial salicylic acid so completely as to yield a product, physically, chemically and pharmacologieally ilentical with the "natural." And the author of this work alvises the use of the artificial salicylie acid thus purified. The seeond experimental work is that of Stockvis. This, we have seen, means, if it menns mything, that the artificial and "matural" salicylates have the same qualitative actions, but that the "natural" is milder, though no less fatal. T'he last experimental work, that of Waddefl, gives very strong evidenee that the cheapest procurable artificial salicylates of the present day are in no way different pharmacologically from the costly "natural."

In the period of thirty-eight yenrs during which time the artificial salicylates have been in use in medicine, there are to be found, in the entire realm of accessible literature, less than twenty-five communications dealing, even casually, with the relative advantages of the artificial and the "natural" salicylates. In all these years many thousands of patients have been treated with large doses of the artificial salicylates and many of the ablest clinicians and the most acnte observers in Englanel, America nnd on the Continent have watehed the results ct such treatment. Yet there ure a scant fifteen who have been led to report these preparations as being more harmful than any other form of salicylate administered under similar conditions, and in similar amounts. 'The rest have probably rightly attributed such ill effects as mental excitement, delirium, nausea, vomiting, tinnitus and the like to an excessive amount of the drug or to an jdiosynerasy on the part of the patient, or perhiaps to both.

We have to remember, also, that nearly all of the reports of the deleterious actions of the synthetic salicylates were mude well over ten years ano, and that it is possible that at that time certain samples of these products were badly contaminated.

At the present time the iden of the superiority of the "matural" salicylutes is sectulously fostered by certain manufacturess, rather than by the experiences of the medical profession. ln the "literature" and advertisiments of one of these, Charteris is quoted as one of the powerful advocates of the "natural" salieylates. I would suggest that, in the future, mention should be made of his second and third papers, rather than of the first only.

In eonclusion, let me say that 1 have presented all of the evidence from the literature which I can unearth. I have tried to make the excerpts and quotations in such a way as to present the opinions of the several authors with neither omissions nor alterations, such as might in the least alter the meaning that each wished to convey. Lastly, 1 liave brought out such objections to the evidence on either side of the question as have oceurred to me in the reading of these papers and in the writing of this one. 
From the material at hand there seem to be but two logieal conclusions:

1. 'The evidence in favor of the "natural" salicylates rather than the artificial is extremely slight, or what amounts to the same thing, the evidence against the artificial salicylates is even less.

2. In nearly forty years of use by physicians all over the world, the artificial salicylates have been found quite as eflective as the "natural" and no more liable to produce unfavorable actions under similar conditions than are these vastly more expensive "natural" products.

414 Wast 'J'wenty-Sixth Street.

\section{A METITOD OT CONTINUOUS DILATATION OF EXTENSIVE URE'THRAL S'TRIC'TURE}

JOSEPLI RIJUS JASTMAN, M.J).

Clinlanl lorofessor of Surgery, Indlana Untversity school of Medictur. INIOIANAPOIIIS

'I'hree decades ago the followers of ()tis, who were very numerous, eut every stricture of the anterior urethri. 'To-day strictures of the par's anterior are rarely cut. 'Whis is owing to the teachings of Oberlaender, Wossidlo, Valentine and Kohlmann, and to the consequent incrense of knowledge and more careful study of the dilatation treatment. It took years to establish the principle that sounds and dilators are not used to stretch strictures. Such an instrument in the urethra exerts a dynamic

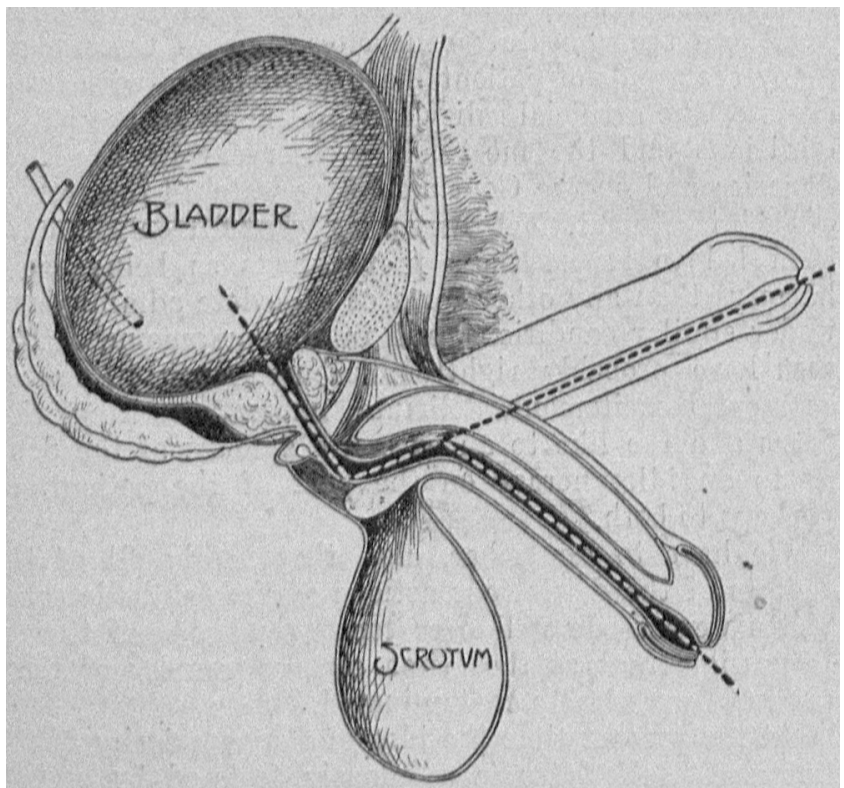

Wig. 1,-Curves at membranous poltlon of mothra nnd pono-

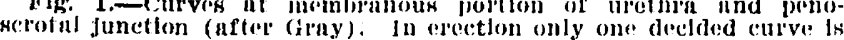
presint.

influence. Aceording to Oberlaender, it induces retrograde metamorphosis, a reconversion of the fibrillary tissues into the original small-eclled deposit, permitting alsorption. It has been intimated that the cells of the infiltrate are rendered soluble or diffusible or absorloblyle by peptonization; and again that absorption is favored by a teasing apart of cells, as in the Bier metlod of inducing artificial hyperemia. Whatever theory may finally explain the phenomenon, it may be fairly stated that pressure absorption of methral inflammatory infi]trations, solt and lasd, is an accredited and authentic olservation.

Alter perineal section for strictures that narrow both the anterior and posterior divisions of the urethral ramal, it has been my practice to drain the bladder by the natural route, leaving a large soft rubber catheter in the urethra. 'This plan has some advantages. 'The period of convalescence is shortened, since the perineal wound closes more promptly if the mine be drained through the catheter. 'The urinary salts which irritate the mucosn and favor stricture formation (Keyes) are not permitied to toueh the urethra. 'The caliber of the urethra is maintained or even increased, and the subsequent passage of instruments is rendered easy. Much of the tedious. work of after-treatment, such as somding, becomes unnecessary or is decidedly lessened. Solt and hard infiltrations of the jurs anterior are removed by the pressure absorption indueed by the presence of the cutheter.

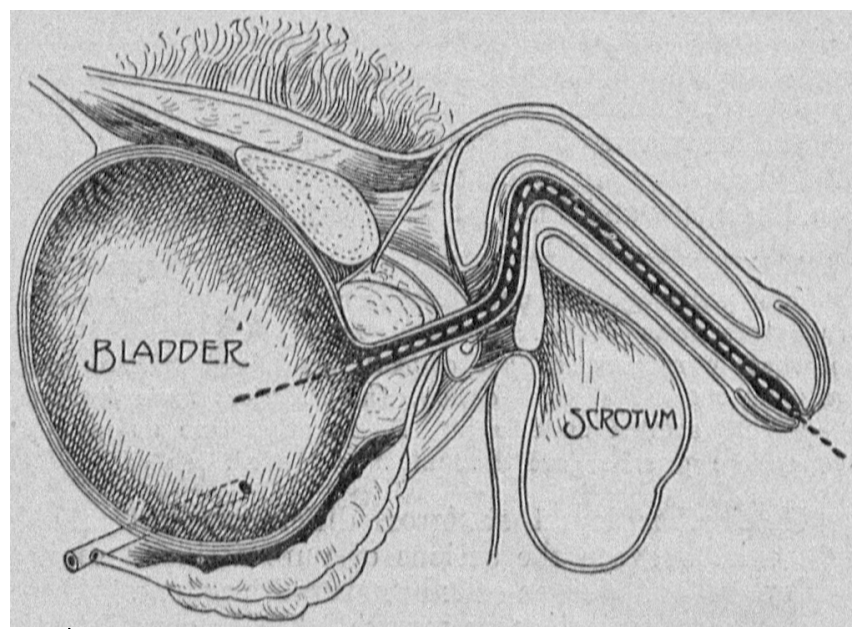

Wigr. 2.-Shurp penowerotal mugle. The nolmul angle is shown

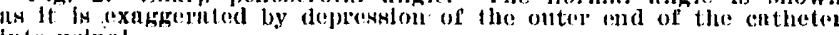
linto uinut.

If a perineal drain ulone be used, there is, of course, no continuous dilatation of the anterior vrethra.

There is, however, one defensible objection to the use of the dilating catheter if employed as described albove. lying in the urethra and extending from the bladder to the external meatus it usually becomes sharply curved or angulated in the pars membranacea and at the penoscrotal juncture. 'l'he pressure induced by the sharply flexed catheter at the penoserotal angle has led to abseess formation or extensive inflammatory reaction often enough to suggest the need of a departure from the plan of using the same catheter for drainage and dilatation, and of enploying instend two large elastic solt rubber catheters, one as a perineal drain, the other for dilatation of the pars anterior.

It has been observed by those who are accustomed to drain the bladder through the urethra for certain conclitions that a small solt thin-walled rubloce catheter lous less tendency to cause abscess than a large rubber tube with thicker wals. 'The former, however, is of mueh less value as a dilator, and is more difficult to retain in position. If the outer end of the catheter be drawn up over the abdomen and comnected with a urinal at the side of the bed, one eurve is made of the urethral canal, and the danger of abseess lessened. It is not easy, however, thus to hold a catheter in place becanse of unavoidable traction.

From Figure 1, it will be seen that if the external mentus be not depressed as it nsually is in catheter drainage through the urethra, there need be no shan'p andulation at the penoserotal juncture. Il' the penile portion of the urethria be elevated the entire pars anterior becones quite straight. 